\title{
COSMOPOLITISMO E GEOGRAFIAS DA LIBERDADE
}

ANDRÉ CARMO ${ }^{1}$

David Harvey é, indiscutivelmente, o mais reconhecido geógrafo da actualidade. A sua trajectória ao longo das últimas quatro décadas assinalou alguns dos mais importantes marcos da ciência geográfica contemporânea. Apesar de a sua obra estar firmemente ancorada numa profunda reflexão em torno de conceitos cruciais para a geografia, há muito que transcende os seus limites disciplinares. Neste sentido, parece-nos pertinente olhar atentamente para a sua mais recente obra Cosmopolitanism and the Geographies of Freedom $(\mathrm{CGF})^{2}$. Resultado de um conjunto de seminários proferidos por Harvey na Universidade da Califórnia ao longo do ano de 2005, CGF encontra-se dividido em dois grandes blocos, que parecem animados de uma tensão dialéctica, bem ao jeito da tradição marxista na qual o autor se filia.

No prólogo são expostas as motivações subjacentes à produção de CGF, nomeadamente, o facto de existirem um conjunto de valores políticos universais (ex: liberdade, cidadania, democracia) que, desprovidos de qualquer contextualização de natureza geográfica podem legitimar um conjunto de interpretações, leituras e até mesmo intervenções de natureza política condenadas ao fracasso. Um dos exemplos utilizados pelo autor para ilustrar o seu raciocínio é a visão anglo-americana, associada aos governos de George W. Bush e Tony Blair, de uma nova ordem mundial alicerçada numa defesa intransigente da democracia e das liberdades, sobretudo individual e do mercado, que legitimou uma intervenção militar no Iraque.

O primeiro bloco, designado Universal Values, é constituído por cinco capítulos. Harvey começa por relembrar a importância de Kant, não só para as actuais propostas cosmopolitas, mas também para a própria construção da geografia enquanto ciência. Infelizmente, as fundações antropológicas e geográficas da filosofia política kantiana repousam sobre preconceitos que, aqui e ali, como iremos ver adiante, reemergem nalgumas das mais sofisticadas leituras da actualidade.

Em seguida convoca um conjunto de escritores associados à tradição pós-colonial, para ajudar a desmontar o universalismo do projecto liberal. Defende que tanto a geografia como a antropologia são fortemente reprimidas na teoria liberal, por serem consideradas irrelevantes. Porém, no momento de aplicação concreta da teoria, mostram a sua relevância. Foi a universalização do projecto liberal que legitimou, nos processos de colonização,

1 Geógrafo, IGOT-UL. E-mail: carmo@campus.ul.pt.

2 Harvey D (2009) Cosmopolitanism and the Geographies of Freedom, New York: Columbia University Press. 
as estratégias paternalistas de infantilização dos autóctones e, no limite, a sua erradicação.

Harvey procede, depois, como que a uma actualização da análise do projecto liberal, através da exploração da sua formulação contemporânea - o neoliberalismo. Ao estabelecer um paralelo entre o avanço do projecto neoliberal e o crescimento das desigualdades sociais à escala global, põe a nu todas as suas fragilidades.

No quarto capítulo, elenca um conjunto bastante diversificado de propostas actuais para a construção do cosmopolitismo. Concebe três possibilidades através das quais o cosmopolitismo pode emergir: i) da reflexão filosófica; ii) do reconhecimento das necessidades sociais e humanas básicas; iii) de movimentos sociais comprometidos com a transformação do mundo. Harvey acredita que é esta última possibilidade que parece ter maiores possibilidades de sucesso e, por isso, reconhece o mérito das propostas de autores, como Boaventura Sousa Santos e Iris Marion Young, que lhe atribuem um grande protagonismo.

Para terminar o primeiro bloco, Harvey recapitula lembrando que o liberalismo, o neoliberalismo e o cosmopolitismo são considerados válidos, independentemente de qualquer contextualização e consideração de natureza geográfica e antropológica. A esta fragilidade, acrescenta uma outra, relacionada com o enviesamento em termos de classe e etnia (isto é eurocentrismo e imperialismo) de que padecem. A incorporação de ambas as preocupações debate-se com duas barreiras principais, nomeadamente, o facto de comprometerem a utilização política de formas de oportunismo selectivo e a impossibilidade de aceitarem a introdução de entropia em modelos universais teoricamente "perfeitos" e sem lacunas. Porém, é na complexidade dos detalhes geográficos que se escondem os "demónios" que conduzem ao fracasso os projectos universalistas.

O segundo bloco, intitulado Geographical Knowledges, é constituído por quatro capítulos. No primeiro, Harvey parte do princípio de que é precisamente pela sua suposta banalidade que os conhecimentos geográficos devem ser problematizados. Em seguida, embarca numa digressão pela história da disciplina. A grande diversidade de tradições e perspectivas leva-o a dizer que a geografia tem um problema de identidade. Todavia, reconhece também que a pluralidade é um ponto forte e não uma fraqueza da disciplina.

Depois, apresenta uma proposta matricial de compreensão do espaço que articula duas dimensões. A primeira cruza espaço absoluto (fixo e imóvel), espaço relativo (processos e movimento) e espaço relacional (sonhos, memórias e fantasias). A segunda remete para o pensamento de Lefebvre e cruza espaço material (espaço percepcionado), representação do espaço (espaço concebido) e espaços de representação (espaço vivido). Mantidas em tensão dialéctica, as duas dimensões permitem-nos compreender a realidade de forma integrada e holística.

Posteriormente, explora o conceito de lugar, tentando clarificar alguma confusão conceptual que tende a permanecer no seio da disciplina. $\mathrm{O}$ aspecto mais relevante é o facto de considerar que a clássica dicotomia espaço-lugar só faria sentido se o espaço ao qual se opõe o lugar fosse absoluto. Ora, numa abordagem matricial, esta diferenciação não faz qualquer sentido pois nesse quadro espaço e lugar são inseparáveis, já que ambos são feitos de matéria e processos. Para Harvey, não se pode perceber o lugar sem perceber o espaço. Ao sugerir que the only concept of place that makes sense is one that sees it as a contingent, dynamic, and influential "permanence", while being integrally contained within the processes that create, sustain, and dissolve all regions, places, and spacetimes into complex configurations (p. 194), está também a defender que políticas baseadas no lugar que não sejam capazes de olhar para o espaço estão fadadas ao insucesso.

Por fim, debruça-se sobre os trabalhos de Jared Diamond e Jeffrey Sachs, assinalando algumas das suas contradições e inconsistências, nomeadamente, no que diz respeito à apre- 
sentação de leituras bastante sofisticadas mas ancoradas num raciocínio do tipo determinista. Em ambos os casos, as actuais desigualdades geográficas, no desenvolvimento e na distribuição global da riqueza, são explicadas pelas condições ambientais. Práticas colonialistas, imperialistas e um capitalismo predador, tornam-se insignificantes quando comparadas com o legado ambiental. Por outro lado, mesmo um autor como Daron Acemoglu que critica Diamond e Sachs na base de que a desigualdade global está relacionada não com os factores geográficos mas sim com o funcionamento das instituições apresenta, segundo Harvey, uma argumentação frágil, na medida em que sugere que a geografia global se manteve praticamente inalterada nos últimos 500 anos e, para além disso, não reconhece que relativamente à distância e localização, a medida relevante seja o espaço-tempo dos transportes e comunicações e não a distância física do espaço absoluto.

Como resposta, Harvey defende que só podemos compreender a dialéctica da natureza, das transformações sócio-ecológicas, se utilizarmos como instrumento de análise o método dos momentos. Este gravita em torno de seis momentos: i) tecnologia; ii) natureza; iii) actividade produtiva; iv) reprodução do quotidiano; v) relações sociais; vi) concepções mentais do mundo. Todos devem ser considerados na sua relação com os outros e mantidos numa tensão dialéctica. Esta forma de compreender o mundo é, para o autor, a essência do materialismo histórico-geográfico, que deve ser incorporado em qualquer projecto cosmopolita.

CGF termina com um epílogo no qual a matriz dialéctica é testada através da análise de dois conceitos-chave para a teoria social contemporânea: indivíduo e Estado. Não obstante, Harvey defende também que o quadro teórico apresentado pode ser também usado para explorar conceitos tais como cidade, região, bairro e comunidade.

Pensamos que com CGF, Harvey contribuiu, uma vez mais, para o desenvolvimento do quadro teórico da geografia, sem no entanto ignorar as implicações políticas inerentes a esse processo. Não obstante, devem salientar-se dois aspectos: i) a construção matricial do espaço-tempo, na medida em que permite ultrapassar algumas das limitações das dicotomias clássicas; ii) a ideia de abandono de formas de raciocínio causal mecanicista, em detrimento de formas de pensamento dialéctico em que cada um dos aspectos se relaciona com todos os outros, centrando a análise nos processos e não nos sujeitos/objectos em si mesmos. 